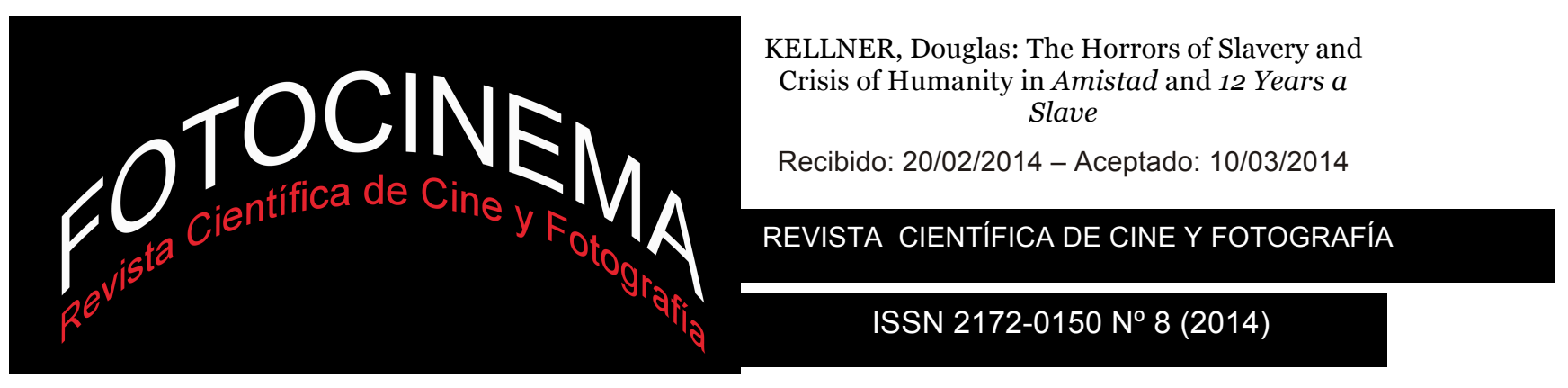

\title{
THE HORRORS OF SLAVERY AND CRISIS OF HUMANITY IN AMISTAD AND 12 YEARS A SLAVE
}

\section{HORRORES DE LA ESCLAVITUD Y CRISIS DE LA HUMANIDAD EN AMISTAD Y 12 AÑNOS DE ESCLAVITUD}

\author{
Douglas Kellner \\ Universidad de California, Los Ángeles
}

\begin{abstract}
:
Solomon Northup's testimonial 12 Years a Slave (1853) tells the heart-wrenching story of how a free black man living in New York was captured by slave traders and forced to live as a slave on southern plantations in the 1840 os under inhuman and oppressive conditions. Writing up and publishing his experiences, Northup presents a searing portrayal of the evils of slavery that influenced abolitionist arguments and movements in the pre-Civil War period as debates over slavery intensified, leading to the bloodiest war in American history.

The horrors of slavery created a crisis of humanity in the United States in which a class of Americans participated in slave-holding, a practice that was seen in some parts of the country as causing a crisis of humanity in which millions were subjected to inhuman living working and living conditions. While the U.S. constitution and American revolution had produced "liberty and justice for all," and proclaimed equal rights before the law obviously the system of slavery created a crisis for U.S. constitutional democracy that led to a Civil War that almost tore the country apart. Hollywood cinema has traditionally been reluctant to portray the horrors of slavery, providing idealizations of slavery in films like Birth of a Nation (1915) and Gone with the Wind (1939), and tending to ignore it during the highly charged post-World War II period that featured an intensifying powerful Civil Rights movement.

Steve McQueen's 2013 film provides a powerful cinematic rendition of Northup's 12 Years a Slave and has been affirmed as one of the one most powerful films on slavery ever produced, a film being nominated for and winning multiple awards as I write in winter 2014. In this article, I will contrast Gordon Parks' relatively unknown PBS "American Experience" film of 1984 Solomon Northup's Odyssey with McQueen's film, although I open with a look back at Steven Spielberg's Amistad (1997), which presents a 1839 slave revolt on a ship bound to the Americas and the subsequent trial of the rebels. The Amistad rebellion and trial, like Northup's book, influenced the abolitionist movement and
\end{abstract}

is a significant, although often forgotten moment in U.S. history. Hence, the current discussions of McQueen's highly acclaimed film provide the opportunity for a look backwards at a painful moment in U.S. history and for discussion of different modes of cinematic representation of slavery and how a crisis of humanity in the U.S. has received different modes of cinematic representation. Accordingly, I will contrast Spielberg's film with Parks' and McQueen's presentations of slavery in their versions of Northup's 12 Years a Slave. Although Spielberg's Amistad contains many features of dominant American ideology and an individualist Hollywood narrative which informs Spielberg's liberal cinema, it is perhaps the most modernist and one of the most compelling of Spielberg's films that deserves a second look and comparison with Park and McQueen's 12 Years a Slave.

I will, however, first examine Amistad which provides a broader panorama of the system and complex effects of slavery in U.S. life and history than Parks' powerful narrative of Northup's book and McQueen's more concentrated and intense focus on the horrors of slavery in 12 Years a Slave. I contrast Parks' use of classical realist modes of representation with McQueen's aestheticized and modernist version. Juxtaposing different cinematic representations of slavery and cinematic renditions of Northup's slave testimony, I show how McQueen's film provides a modernist version of Northup's text that forces the audience to experience the horrors of slavery and crisis of humanity, while Parks uses a conventional realist narrative to tell Northup's story and depict the institutions of slavery. These films, I believe, are among the best English-language cinematic efforts to engage the "peculiar" and arguably monstrous American institution of slavery that continues to shape our history today into the Obama era.

\section{Resumen:}

El testimonio personal de Solomon Northup en 12 años de esclavitud (1853) relata de manera desgarradora la captura de un afroamericano 
libre, ciudadano de Nueva York, a manos de unos traficantes de esclavos y su traslado a las plantaciones del sur en la década de 1840, donde inicia una nueva vida en condiciones inhumanas y opresivas. En sus memorias, Northup recrea el escenario ominoso de la esclavitud en los años previos a la Guerra de Secesión, lacra que encendió los argumentos del movimiento abolicionista e intensificó los debates en torno a la esclavitud, hasta el punto de conducir a la nación a una de las guerras más sangrientas de la historia estadounidense.

Los horrores de la esclavitud han provocado una crisis de humanidad en la conciencia nacional. En determinados territorios del país, una clase social contaba con esclavos en propiedad y esta práctica sometió a una vida inhumana a millones de personas. Si bien tanto la Constitución como la Revolución se habían obrado bajo el lema "libertad y justicia para todos" ("liberty and justice for all”), y habían proclamado la igualdad de derechos ante la ley, la institución esclavista originó una crisis democrática y constitucional que desgarró el país con una guerra civil. Tradicionalmente, el cine estadounidense, y Hollywood en particular, se han mostrado reacios a retratar los horrores de la esclavitud e incluso han proporcionado idealizaciones de la esclavitud en películas como El nacimiento de una nación (1915) y Lo que el viento se llevó (1939). Tras la segunda guerra mundial, Hollywood tendió a ignorar el tema durante un período en que, sin embargo, surgió un poderoso movimiento a favor de los derechos civiles.

La película de Steve McQueen producida en 2013 ofrece una versión cinematográfica del relato autobiográfico de Northup, también titulada 12 años de esclavitud. Sin duda se trata de uno de los filmes más impactantes jamás realizados, nominado en 2014 a nueve Óscar y finalmente premiado por la Academia de Hollywood con el galardón a la mejor producción, a la mejor actriz de reparto y al mejor guion original. El presente trabajo se propone establecer un contraste entre la película de McQueen y Solomon Northup's Odyssey, un título relativamente desconocido, realizado por Gordon Parks en 1984. Además, en este contexto crítico, se ofrece una retrospectiva del filme de
Steven Spielberg Amistad (1997), que relata la revuelta de esclavos ocurrida en 1839 a bordo de un barco negrero en aguas caribeñas y el posterior juicio a los rebeldes.

Como el libro de Northup, el caso de la goleta "Amistad" también influyó decisivamente en el movimiento abolicionista, aunque se trate de un episodio a menudo olvidado. Por este motivo, el éxito y el debate ocasionados por 12 años de esclavitud ofrecen un contexto propicio para revisitar uno de los momentos más dolorosos de la historia del país y, al mismo tiempo, examinar de manera crítica las distintas representaciones cinematográficas de la esclavitud en cuanto crisis de humanidad. Es posible que Amistad contenga numerosos tópicos de la ideología norteamericana dominante, así como una visión individualista típica de Hollywood que se mezcla e informa el cine más progresista de Spielberg. Sin embargo, quizás sea también el más innovador de cuantos ha realizado y uno de los más sugerentes e impactantes, factores que lo hacen merecedor de una segunda mirada y de una comparación crítica con los títulos de Park y de McQueen.

En primer lugar se examinará Amistad, que proporciona un panorama más amplio del sistema esclavista así como los complicados efectos históricos de la esclavitud, por encima del poderoso retrato de Park y el reciente filme de McQueen, más centrado en la descripción del horror humano. Se contrastará el realismo clásico propio de la representación de Parks con la versión de McQueen, esteticista y modernista. $\mathrm{Al}$ contraponer diferentes representaciones fílmicas de la esclavitud en torno al testimonio de Northup, se mostrará cómo el filme de McQueen proporciona una versión modernista del texto autobiográfico que empuja a la audiencia a experimentar los horrores de la esclavitud, mientras Parks emplea una visión narrativa convencional en su representación de la esclavitud a través del relato de Northup. En mi opinión, las tres películas son una muestra de los mejores esfuerzos realizados en lengua inglesa para recrear la monstruosa institución esclavista durante la era Obama.

Palabras clave: Esclavitud; Crisis de la humanidad; Narrativas de la crisis; Hollywood; Steven Spielberg; Steve McQueen

Keywords: Slavery; Crisis of Humanity; Narratives of Crisis; Hollywood; Steven Spielberg; Steve McQueen

1. There is a scholarly edition of Solomon Northup, Twelve Years a Slave, co-edited by Sue Eakin and Joseph Logsdon, Library of Southern Civilization: Louisiana State University Press, 1968. The book was expanded and re-issued in August 2013 as Solomon Northup: The Complete Story of the Author of Twelve Years a Slave, edited by Clifford W. Brown, and Rachel Seligman (New York Praeger, 2013). I bought a reproduction of the original publication from Amazon brought out to coincide with the release of McQueen's film with the original publication material in the frontpiece, from which I'll cite pages; the subtitle of the original carries the eyebrowraising Narrative of Solomon Northup, citizen of New-York, kidnapped in Washington city in 1841, and rescued in 1853, from a cotton plantation near the Red River, in Louisiana; I also draw from an online version of the original printed text at https://archive.org/stream/twelveyearsslaveoonortuoft/twelveyearsslaveoonortuoft_djvu.txt (accessed December 15, 2013).

2. The conception of classical Hollywood narrative cinema that I will use is articulated in David Bordwell, Janet Staiger, and Kristin Thompson, The Classical Hollywood Cinema: Film Style \& Mode of Production to 1960 (New York: Columbia University Press; Reprint edition 1985). On modernism, I am using the concept delineated by Stephen Eric Bronner and Douglas Kellner in our Introduction to Passion and Rebellion: The Expressionist Heritage, co-edited by Stephen Eric Bronner and Douglas Kellner (New York: Universe Books and Bergin Publishers (USA) and London: Croom Helm (England), 1983; second edition, Columbia University Press, 1988). Introduction online at http://www.gseis.ucla.edu/faculty/kellner/Bronner_Kellner.pdf (accessed on December 20, 2013). See also Stephen Eric Bronner's collection of articles on modernism, Modernism at the Barricades: Aesthetics, Politics, Utopia (New York: Columbia University Press, 2012). 


\section{Steven Spielberg's Amistad}

Spielberg's historical epic Amistad depicts the horrors and inhumanity of slavery through the story of an almost forgotten 1839 slave revolt aboard a Spanish slave ship off the coast of Cuba. A cargo of Africans who had been captured in Sierra Leone, loaded into a slave trader that sailed to Havana, sold into slavery in Cuba, and put aboard the ship La Amistad to be transported to a life of slavery on the other side of the island of Cuba, revolted and took over the ship. Many of the crew and the blacks working with them were killed, although two of the Spanish crew were spared to help the rebels navigate the ship to what was hoped would be a safe port. The Spaniards, however, managed to aim the direction of the seized ship toward North America where it was boarded by American naval troops off the coast of Long Island, who arrested the mutineers and took them to prison in New London, Connecticut, where they would go on trial, in a media spectacle that captured the attention of the nation and furiously fuelled the fateful national controversy over slavery3.

La Amistad is ironically the Spanish word for friendship, while the story of the Amistad rebellion demonstrates the unfriendly and inhuman nature of the slave trade. In Spielberg's narrative, "Amistad" also refers to the friends of the Africans in the abolitionist movement, who saw the inhumanity of slavery and joined with rebellious slaves to fight the institution of slavery. The Amistad rebellion and the subsequent trial played a significant role in mobilizing abolitionists at the time, and thus was a significant event leading to the Civil War, as anti-slavery forces strongly side with the rebels while pro-slaver forces sided with the ship owners and Spanish government which demanded the return of the ship and prisoners.

As historian Marcus Rediker notes, the story of the Amistad rebellion was wellknown in the build-up to the Civil War with abolitionists and journalists writing extensively on the event, playwrights, novelists, and songwriters memorializing the rebellion and the trial, and with the public closely following the long trial and its aftermath. Yet by the $20^{\text {th }}$ century, Rediker claims that the story of the

\footnotetext{
3 For a clear narrative of the Amistad story, see (Myers, 1998). Myers, a five-time recipient of the Coretta Scott King Award and winner of awards for "Outstanding literature for Young Adults," provides a clear, compelling, and engagingly illustrated account of the Amistad struggle and its place within the U.S. Civil Rights and liberation African-American struggles.
} 
Amistad rebellion was largely forgotten until Spielberg's film brought again the story to wide public attention (Rediker, 2012, p. 3)4.

Spielberg tells how the film's producer Debbie Allen brought the story to him, and that he saw it as a serious epic history lesson that should be presented to the American public5. Spielberg had just begun his new Dreamworks studio and sought a prestige property that would help promote his studio as a producer of important movies (Friedman, 2006, pp. $269 \mathrm{ff}$ ). He was at the time one of the most important and influential Hollywood directors with megahits like Jaws (1975), Close Encounters of the Third Kind (1977), the Indiana Jones franchise (1981, 1984, 1989, 2008), E.T. (1982) and the Jurassic Park films (1993 and 1997 with the 2008 film directed by Joe Johnson). Spielberg had also attempted to make more serious films like The Color Purple (1985), based on Alice Walker's novel of a young black woman growing up in the South, and Empire of the Sun (1987), a rendering of J.G. Ballard's semi-autobiographical novel of growing up in Shanghai during the Japanese occupation in World War II. While these films received a mixed audience and critical reception, his film Schindler's List (1993), about a German businessman who saved Jews in the Second World War, received enthusiastic reviews and won Spielberg his first Academy Awards for Best Director and Best Picture. Amistad thus follows Spielberg's practice of mixing serious epic historical dramas with his more popular entertainment films, taking on an important episode in the revolt against slavery and struggles toward freedom and equality in U.S. history.

\footnotetext{
4. Marcus Rediker, author of the renown book The Slave Ship: A Human History (Baltimore: Penguin reprints 2008), wishes to tell the story of the Amistad rebellion from below (p. 12). He skillfully brings to life and personalities and experiences of the rebellious slaves and to situate their story within the context of the global revolts going on at the time against slavery, of which the Amistad rebellion is an important part. Rediker also provides a well-researched and compelling portrait of the abolitionist movement and the specific American white and black individuals who helped the Amistad rebels in their struggle for freedom and to return to their homeland in Africa.

5. On the DVD of Amistad, both Spielberg and producer Debbie Allen tell how Allen brought the story idea to Spielberg. On the TCM movie site, David Sterritt notes: "The idea of filming the Amistad affair came from actress and director Debbie Allen, who had run across some books on the subject. After running into fund-raising problems, she brought the project to Spielberg, who wanted to stretch his artistic wings after making The Lost World: Jurassic Park (1997), and was looking for a prestige production to direct for DreamWorks SKG, the studio he'd recently co-founded. Spielberg was an unlikely person to tackle the Amistad story, since his previous picture about black characters, The Color Purple, had been badly received by the black community, its eleven Oscar® nominations (no wins) notwithstanding. 'I got such a bollocking for The Color Purple,' he told a New York Times interviewer, 'I thought, I'll never do that again.' But Spielberg evidently saw great potential in the Amistad story, and decided to take it on, even though his crowded schedule meant doing pre-production while DreamWorks was still being launched and postproduction while Saving Private Ryan (1998) was before the camera." David Sterritt, “Amistad," Turner Classic Movies at http://www.tcm.com/this-month/article/188770\%7Co/Amistad.html (accessed October 31, 2013). Allen had also acted in Roots; see http://en.wikipedia.org/wiki/Debbie_Allen (accessed October $31,2013)$.
} 
Amistad opens dramatically during a storm which flashes strobe-effect lighting in the opening sequence, beginning with a mysterious close-up of what turns out to be the eyes of a black man, then shown chiseling a metal object from wood. Spielberg cuts rapidly, showing splotches of blood on the man's hand, a metal nail being ripped out of the plank of the deck, followed by a long shot of the man using the nail to break the lock of the manacles that bound him to the ship. Cinque frees another and a quickly-edited montage shows groups of black men breaking free of the manacles that had kept them in bondage ${ }^{6}$. With dramatic music, thunder and lightening, fragmentary images, and quick cutting, the modernist opening produces a jarring sense of dislocation, intensified as the blacks are torn loose from their chains and appear on deck, resolved to take over the ship.

The fast editing, strobe-like effects during the storm, and dramatic action continue as the black men attack the ship's captain who fires back, hitting two of the attackers and stabbing one with a bayonet attached to the end of his rifle. The white captain is overpowered, however, by the rebellious Africans, and he is stabbed to death by a powerful black man who emerges as the leader of the slave revolt and who will eventually be introduced to the audience as Joseph Cinque (Djimon Hounsou), who emerges as a central figure of the film.

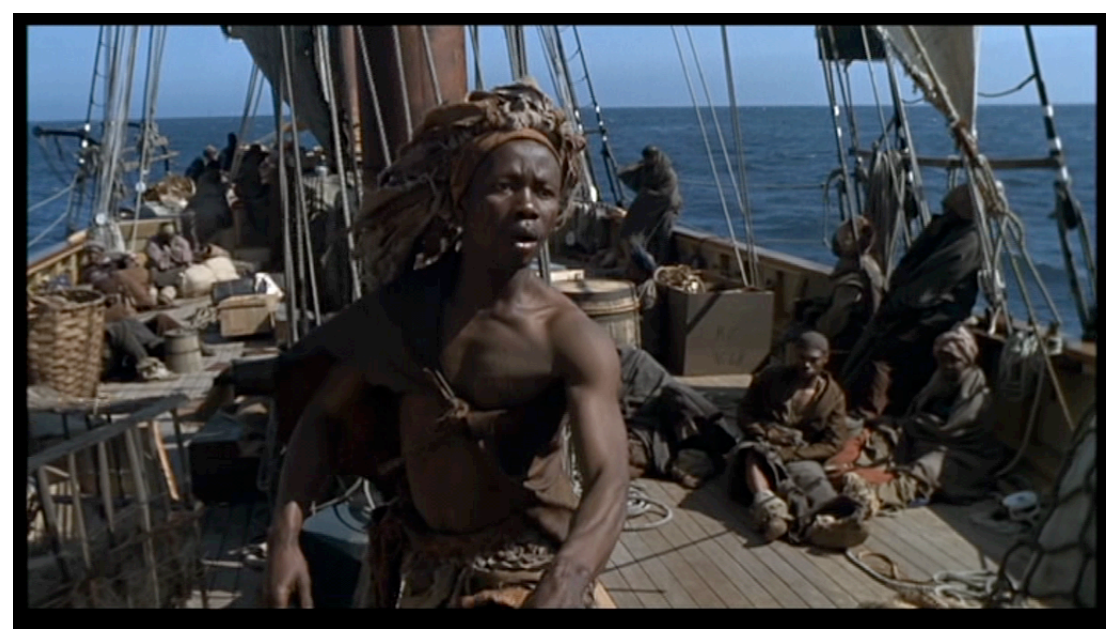

Amistad (Steven Spielberg 1997). Cinque (Djimon Hounsou) on board the slaveship after the rebellion

The initial uprising depicts the group effort of the rebels who fight the ship's armed crew with knives, sabers, and sticks, seizing control through guerilla like

\footnotetext{
6. Rediker writes that "Cinque found a loose nail on deck and used it to pick the central padlock. Whether the locks were broken or picked, it was significant that two of the forty-nine enslaved men were blacksmiths, who knew the properties of iron intimately from their work" (op. cit., p. 75).
} 
action. Yet the image of a powerful leader is highlighted during the rebellion sequence, first, beginning the literal process of freeing the Africans from their chains, and then in images of Cinque standing out from the group and framed in heroic poses, illuminated by bright lighting, and thunderous music during the uprising. Throughout the film, Cinque will be positioned as the natural leader of the rebels who is the center of cinematic representation and the key narrative link between the major characters.

Spielberg and cinematographer Janusz Kaminski reportedly constructed the film's visual style by deploying images from the paintings of Francisco Goya, whose horrors of war and incarceration pictures helped shape opening images of the Africans' imprisonment in the ship and revolt, and then the later prison scenes during the trial7. Spielberg and his crew also intended to provide accurate historical representations of the Amistad rebellion and subsequent trial and to tell much of the story from the standpoint of the Africans (Davis, 2000, pp. $72 \mathrm{ff})^{8}$.

The opening and succeeding images portray the Africans as radically other to the white Europeans involved in the slave trade and to the white Americans who must sort out their fate through machinations in the U.S. political and legal system. The African sounds and language are initially untranslatable and frightening to Western ears, and throughout the film the incommunicability between the Africans, their Spanish slave-trading captors, and the Americans putting the African rebels on trial in their mysterious justice system is highlighted. Yet the film's fierce humanism eventually establishes communication and understanding between the African captives and their

\footnotetext{
7. On the influence of Goya on the look of parts of Amistad, see the "Making of" feature and the DVD, and Frank Sanello, Spielberg: The Man, the Movies, the Mythology. Taylor Trade Publications, 2002, p. 272 at Google Publication http://books.google.com/books?id=A6hmQbfOeTAC\&pg=PA271\&lpg=PA271\&dq=Spielberg+Janusz+Ka minski+Francisco+Goya.\&source $=$ bl\&ots $=$ afg3dtl14f\&sig $=v u Q K 35-$ pBkScZYQaO1ur1ToV9rQ\&hl=en\&sa=X\&ei=cx51UrSgL6TAigKo2YCABw\&ved =oCC4Q6AEwAQ\#v=onepa ge\&q=Spielberg\%20Janusz\%20Kaminski\%20Francisco\%20Goya.\&f=false (accessed October 2, 2013). 8. Natalie Zemon Davis describes how Spielberg and his production team employed and consulted historians to try to accurately portray the events depicted, and provides as well historical background on historical misrepresentations of characters and events, as well as criticisms by historians of the film. See Davis, pp. 72ff. on how Debbie Allen brought the story to Spielberg and how they made use of historical advisors to the project.
} 
abolitionist American allies who work to free the rebellious slaves and enable their return to Africa9.

After the dark, stormy, and Goyaesque opening sequence, the film flashes a title "1839" and cuts to a clear blue sky and placid sea, as the rebels wake up in charge of the ship. For a brief period of time, the rebels control the Amistad and attempt to direct it toward Africa, but the treacherous Spanish ship owners Ruiz and Montez, who the rebellious slaves had saved to help with navigation, cleverly sail West toward the sun (and presumably Africa) in the day, but tack North at night toward America. A title "Six weeks" follows, depicting the ship short on water, and when the vessel comes upon Long Island, New York, a strange sequence shows rich Americans on a yacht enjoying a dinner with black servants and classical music, while the liberated slave ship passes by, and both sides look upon the other in wonder, highlighting the class and cultural differences between the groups. The Amistad rebels' freedom is about to come to an end, however. When Cinque and some of the rebels go ashore to get fresh water, a U.S. Navy vehicle encounters the Amistad, and the sailors observe that it is manned by a motley crew of black people. The Americans board the ship, seize it, and arrest all the rebels who will go on trial for mutiny and murder.

The rest of Spielberg's Amistad unfolds as a legal drama, with scenes cutting from the bright lighting in courtrooms and law offices to grimmer scenes of the rebels in prison. Initially, wealthy abolitionists Theodore Joadson (Morgan Freeman) and Lewis Tappan (Stellan Skarsgård) ${ }^{10}$ attempt to persuade former U.S. president John Quincy Adams (Anthony Hopkins) to defend the rebels, but he declines, portrayed as more interested in cultivating exotic plants in a greenhouse garden than involving himself in demanding struggles in the public sphere. Eventually, the abolitionists sign up a real estate lawyer (Matthew McConaughey) to defend the rebels, and in the film he provides a highly

\footnotetext{
9. Rediker indicates that Cinque and others of the slaves labored to learn English while incarcerated, and that abolitionists used former African slaves, who had become freed and had been working on ships as translators. In an amusing scene in Spielberg's film in which the African slaves are being introduced to the abolitionist lawyers who will defend them, a University linguist who supposedly specializes in African languages is utterly unable to translate the Mende dialect of the rebels, and in comic scenes mistranslates completely what the Africans are saying. Soon, however, they will have their own translator, based on a historical figure James Convey played by Chiwetel Ejiofor, see (Rediker, 2012, pp. 11ff, passim) who stars in Steve McQueen's 12 Years a Slave which I discuss below.

10. Spielberg's Joadson character was a composite of several abolitionists, while Tappan was a major historical figure in the movement; Davis regrets that Tappan was not assigned a larger role in Spielberg's narrative (Davis, 2000, p. 79), while many critics wish that the Joadson character and excellent actor Morgan Freeman could have had a more expanded role in the film.
} 
articulate and ultimately effective defense, focusing on the issue of property, and whether the rebels belonged to the ship owners or not ${ }^{11}$.

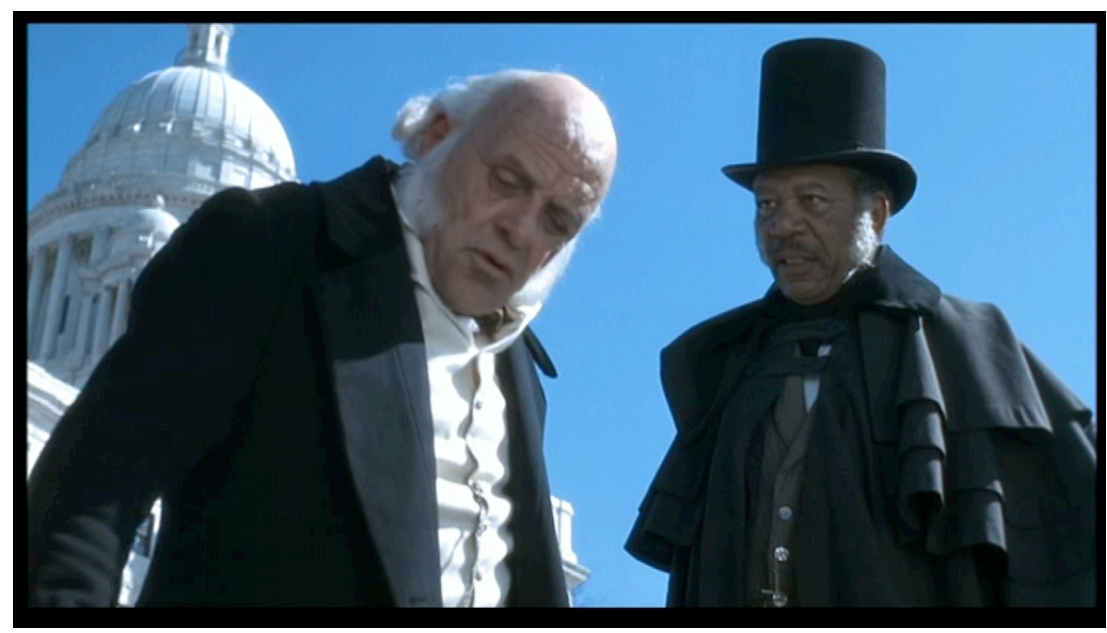

Amistad (Steven Spielberg 1997). President John Quincy Adams (Anthony Hopkins) talks to Theodore Joadson (Morgan Freeman)

\section{Return to home, a major theme in Spielberg's films}

Amistad establishes the geo-political framework of the legal case in a striking shot that cuts from a close-up of Cinque's gleaming eyes in captivity to the eyes of a young woman looking at her reflection on a metal object, and an establishing shot shows her to be Isabella, the Queen of Spain (Anna Paquin). The U.S. President Martin van Buren (Nigel Hawthorne) is first depicted as having no interest whatsoever in the Amistad case and the freedom of the African captives, and throughout is represented as weak and vacillating, fearing losing Southern votes in his re-election campaign if he sides with the Africans and apparently having no strong convictions concerning slavery and freedom of blacks.

The Amistad case is depicted as proceeding fitfully through the American legal system which is portrayed as strange and confusing from the point of view of the Africans. Their initial encounter with their abolitionist allies show them perceiving the hymn-singing and praying Christian abolitionists as "miserable" and sickly, and confronted with their voluble young lawyer Baldwin they think he looks and acts like an "elephant dung scraper," although later one concludes

\footnotetext{
11. Rediker delineates the complex welter of legal issues that were adjudicated in various trials (2012, p. 131f.) At the initial pre-trial hearing in the U.S. District Court charges of piracy and murder were dropped "whereupon the claims of property became the key issue" (p. 132) - as it would in Spielberg's film. For a useful delineation of the subsequent trials, leading up to the concluding Supreme Court decision, see Myers, 1998, pp. 51-74).
} 
that perhaps this is what they need. After a federal District Court in New Haven rules that the Amistad rebels are guilty of "insurrection on the high seas," and will not be released, the Amistad captives are understandably confused and angry, and they are condemned to stand trial in a complicated court case.

Spielberg's film conveys the mixed legal claims of property ownership by Spain, the United States, the Spanish owners of the slaves and of La Amistad, and the American captain and first mate of the US ship that took the Amistad rebels into custody. Scenes with the Spanish Queen Isabella II, whose government is demanding return of the ship and the slaves, and with U.S. president Martin van Buren, dramatize the geopolitical dimensions of the case, while a dinner with van Buren and southern slave apologist Senator John Calhoun (D-SC) highlight the domestic issues involved. At a dinner for the U.S. political elite, Calhoun explains to the Spanish ambassador Calderon that the Northern states consider pro-slavery Southerners as "immoral" and inferior, which Calhoun claims may be so in terms of amassing wealth. But, Calhoun asserts to the crowd, eliminating slavery could well destroy the U.S. economy and a anti-slavery conclusion to the Amistad affair might lead to Civil War in the U.S., portraying the ever present dangers of dissolution of the Union over the contentious issue of slavery.

Aware of the political stakes, van Buren and his allies plot to put what they think is a sympathetic and malleable Judge in charge of the case. Lengthy courtroom scenes follow with the Amistad defense stressing that the slaves are not property but are humans, and, moreover, the Amistad rebels were not slaves on Cuban plantations as the prosecution, Spanish government, and slave traders Ruiz and Montez claim. The defense argues that their defendants are Africans who were captured in their native land, sold into captivity, and brought to Cuba where they were purchased and sent on the Amistad to journey to their new place of enslavement on the other side of Cuba. The trial proceeds fitfully and in one dramatic scene, Cinque stands up and repeatedly says "give us free, give us free," dramatizing the element of struggle for freedom involved in the case ${ }^{12}$.

\footnotetext{
12. According to Myers, (1998, p. 65), Cinque did call out in English “Give us free!,”. As Davis points out in her study of Spartacus, Stanley Kubrick's 1960 film about a Roman slave rebellion also uses the discourse of freedom as a counterpart to slavery as an organizing theme of the film; see (2000, pp. 17ff).
} 
The theme of "home"13 and return to home has long been a major theme in Spielberg's films and informs the thematic of Amistad. One of the most poignant sequences of the film unfolds as Baldwin attempts to bond with Cinque and learn about his home and his experiences. Flashbacks in bright light show a happy Cinque with his wife and children in a green and verdant Africa, followed by harrowing scenes of his capture and the infamous Middle Passage across the Atlantic from Africa to the Americas. This dramatic sequence demonstrates the monstrous and inhumane conditions of the Passage, with Africans packed into a space below deck without proper food, water, exercise, or ventilation. One slave is shown throwing himself overboard in utter despair. Another sequence shows the slave traders flinging a packet of rocks into the ocean, followed by enchained slaves, drowning individuals who were sick or they could not feed. In a courtroom scene a British captain, who had manned British slave patrol ships off the shore of Sierra Leone to intercept illegal slave ships, testified that it was common to throw rebellious, sick, or slaves they could not properly feed overboard and that the inventory of the Tecora, the slave ship that brought over the Amistad captives to Cuba, demonstrated that a significant number of slaves had been discarded on the voyage.

The Amistad defense convincingly makes the case that the rebels are Africans who were captured and enslaved against their will, and the young Judge rules that Ruiz and Montez are guilty of illegal slave trade and will be imprisoned at once, while the Africans are free to go home at the expense of the American government. The joy is short-lived for van Buren and the U.S. government appeal the ruling, and throw the case up to the Supreme Court. Again demonstrating the cultural difference and otherness between the blacks and whites, Baldwin has difficulty in explaining the U.S. legal system to Cinque who is understandably outraged by the decision, but is heartened to learn that a "big chief,” John Quincy Adams, a former President, will help defend him. A subsequent scene shows Cinque meeting Adams in his beloved greenhouse, and an African violet provide a bond of understanding between the two and hope that the Africans will eventually be able to return home.

13. On the importance of the theme of "home" which runs through Spielberg's films, see the book and article by Antonio Sánchez-Escalonilla (2009). 
John Quincy Adams begins his appeal to the Supreme Court by noting that Baldwin had clearly articulated the key issues in the case, but he makes a rousing presentation that the rule of law and justice must prevail in the case. Adams notes that letters from Spanish Queen Isabella constantly refer to our "incompetent courts," and Adams mockingly suggests that she apparently wants a court that does what she wants. The argument that the independence of U.S. courts is a virtue of the system was made in the film earlier when as an aside at a dinner party, a Spanish diplomat complained about the problems with the American "independent" courts, and a gentleman at the table affirms that this is precisely their virtue, an argument made in the concluding scenes of Amistad.

In the culminating crescendo to his speech, Adams deftly situates the trial in the context of the American revolution, while answering an argument made recently in the U.S. government journal Executive Review which asserts that slavery goes back to ancient times and is the "natural state of mankind." Adams retorts that instead it is freedom which is the natural state of humanity, and "the proof is the lengths to which a man will go to regain it once taken." Raising his voice, Adams thunders: "He will break loose his chains. He will decimate his enemies. He will try and try and try against all odds, against all adversity to get home.”

Obviously, Cinque and the Amistad rebels are the referent here, and Adams concludes his case to free them and allow them to go home by evoking the Constitution and Declaration of Independence with its ringing affirmation that "All men are created equal [with] inalienable rights... life, liberty' and so on and so forth." Recalling a conversation with Cinque the previous evening, Adams notes that "when the Mende encounter a situation where there appears no hope at all, he invokes his ancestors." Clinching his argument Adams appeals to American tradition, walking to a wall with portraits of George Washington, Thomas Jefferson, his father John Adams, and other founding fathers. Noting how he rarely invoked his father, Adams concludes: "We desperately need your strength and wisdom to triumph over our fears, our prejudices, ourselves. Give us the courage to do what is right and if it means civil war? Then let it come. And when it does, may it be, finally, the last battle of the American Revolution."

Shortly thereafter, the Supreme Court renders its verdict and the Amistad slaves and their supporters nervously go to the Court, knowing that seven of the nine 
Justices are Southern slave-holders. Justice Story brings down the gavel and renders the verdict, first, addressing the property issue and ruling "they are not slaves, and therefore cannot be considered merchandise." This judgment captures the courtroom's rapt attention as the Chief Justice concludes that the Amistad Africans "are rather free individuals with certain legal and moral rights, including the right to engage in insurrection against those who would deny them their freedom. Therefore, it is our judgment, with one dissension that the defendants are to be released from custody at once. And, if they so choose, be returned to their homes in Africa."

\section{Confronted visions of U.S. legal and political system}

Judge Story brought down the gavel, the courtroom dispersed, and Steven Spielberg has closed his argument, providing ideological legitimation of the U.S. system of justice. As Spielberg's Lincoln (2012) attempted to demonstrate that the political process in the United States works through its detailed dissection of the complicated process whereby President Lincoln and his team mobilized votes in Congress to pass the controversial and divisive 13th Amendment (Kellner, 2013), in Amistad, the narrative makes the argument that despite all the complexities and competing interests, the U.S. legal and political system is rooted in a functioning system of constitutional democracy that provides justice for all. Such an ideological conclusion was contested by historian Eric Foner who argues that:

The film gives the distinct impression that the Supreme Court was convinced by Adams' plea to repudiate slavery in favor of the natural rights of man, thus taking a major step on the road to abolition.

In fact, the Amistad case revolved around the Atlantic slave trade - by 1840 outlawed by international treaty - and had nothing whatever to do with slavery as an domestic institution. Incongruous as it may seem, it was perfectly possible in the nineteenth century to condemn the importation of slaves from Africa while simultaneously defending slavery and the flourishing slave trade within the United States.

In October 1841, in an uncanny parallel to events on the Amistad, American slaves being transported from Virginia to Louisiana on the Creole seized control of the ship, killing some crew members and directing the mate to sail to the Bahamas. For fifteen years, American Secretaries of State unsuccessfully badgered British authorities to return the slaves as both murderers and "the recognized property" of American 
citizens. This was far more typical of the government's stance toward slavery than the Amistad affair.

Rather than being receptive to abolitionist sentiment, the courts were among the main defenders of slavery. A majority of the Amistad justices, after all, were still on the Supreme Court in 1857 when, in the Dred Scott decision, it prohibited Congress from barring slavery from the Western territories and proclaimed that blacks in the United States had "no rights which a white man is bound to respect." (Foner, 1998).

Not only does Amistad present an ideological whitewash and idealization of the U.S. judicial system, but Spielberg and his team have hardly any women in the film with active voice and participation. None of the major protagonists are shown engaged in conversation with women, and the only women portrayed are abolitionists and black slave women who are positioned throughout as watching history unfold, mute objects passively observing the male subjects grapple with their society's key issues, determining the fate of the nation and the Amistad rebels. Thus while it is highly salutary that Spielberg produced such a detailed and engaging historical epic about a key episode in American history that had been largely forgotten, his achievement is limited by the ideological and representational limitations of Spielberg's cinema.

Yet one can agree with the late Roger Ebert that: "What is most valuable about "Amistad" is the way it provides faces and names for its African characters, whom the movies so often make into faceless victims. The captive called Cinque emerges as a powerful individual, a once-free farmer who has lost his wife and family. We see his wife, and his village, and something of his life; we understand how cruelly he was ripped from his life and ambitions. (Since it was the policy of slavery to destroy African families, these scenes are especially poignant)" (Ebert, 1997). Spielberg's cinema, however, is highly individualistic and highlights and idealizes Great Men like Cinque, John Quincy Adams, and Roger Baldwin, who rises in the film from mediocre real estate lawyer who initially sees the Amistad trial as a property issue, to one who grasps the moral and political dimension of the film and bonds as a brother with the noble Cinque ${ }^{14}$. While there appear representations of the abolitionist movement, the leading abolitionists are bit players to the Heroic Men who dominate the film, as is usual in Spielberg's patriarchal male cinema.

14. Davis claims that the historical Baldwin had worked for abolitionist causes and was from the beginning strongly committed to the moral and political dimensions of the case (2000, pp. 79-80). 
Amistad ends with an ironic montage that presents the events that followed the trial and historical fates of the major players. Spielberg shows the British Royal Marines destroying the Lomboko Slave Fortress, and freeing Africans from its dungeons, with the British Captain Fitzgerald (Peter Firth) telegraphing U.S. Secretary of State Forsythe, who had denied the fortress's existence, that indeed the Slave Fortress no longer exists. Graphic titles inform us that President Martin Van Buren lost his re-election campaign to William Henry Harrison, and that Queen Isabella II continued to demand the return of the slaves and the Amistad - until the fall of Atlanta during the American Civil War when she gave it up. Heroic images and music reminiscent of Stalinist cinema show Cinquè and his fellow Africans returning on a ship to their home, dressed in white, the West African color of victory, accompanied by the translator James Covey. Yet a postscript says that Cinquè returned to find his country embroiled in civil war and his wife and child missing, likely sold into slavery ${ }^{15}$.

Amistad received mixed reviews and was ultimately one of Spielberg's most unsuccessful movies at the box office, with a lifetime gross of only $\$ 44,229,441^{16}$. Although nominated for Oscars in four categories, it received no Academy Awards. Historians criticized what they found to be negative representations of evangelical abolitionists, exaggeration of the historical significance of the Amistad revolt, and misrepresentation of some of the historical figures and details of the episode ${ }^{17}$. Spielberg, producer Debbie Allen, and scriptwriter David Franzoni claimed in various reviews that they "consciously chose to downplay the role of the white abolitionists and to concentrate on the Africans, particularly the charismatic Cinque," (Friedman, 2006, p. 271) wishing to avoid the narrative where the Good White Man comes to save the blacks, although Amistad is not completely innocent of that charge as I note above.

In retrospect, the virtue of Spielberg's Amistad is rescuing a forgotten historical episode and bringing to public awareness the monstrosity of the institution of slavery, virtues that would be replicated in the rediscovery of Solomon

\footnotetext{
15. For Rediker's description of subsequent fate of the Amistad case participants, (2012, pp. 224ff).

16. See http://www.boxofficemojo.com/search/?q=Amistad (accessed December 21, 2013). Most of Spielberg's films gross hundreds of millions.

17. For a detailed analysis of the film's reception and criticism by historians, see (Friedman, 2006, pp. 269282; Davis, 2000, pp. 81ff).
} 
Northup's 12 Years a Slave. Spielberg deploys the resources of the classical Hollywood cinema to make Amistad, although moments display modernist flourishes, and the film is more didactic than most of Spielberg's Hollywood entertainment extravaganzas. Conventional realist Hollywood aesthetic and political strategies would be replicated by Gordon Parks in his cinematic renditions of Solomon Northup's narrative, while Steve McQueen would employ more modernist strategies of representation in his acclaimed depiction of a forgotten moment in U.S. history.

\section{Gordon Park's and Steve McQueen's Cinematic Portrayals of} Solomon Northup's 12 Years a Slave

While it is admirable that Spielberg and his associates resurrected an almost forgotten incident of slave rebellion and called attention to the monstrosity of slavery in Amistad, the film did not really deal with the evils of slavery in the Americas. Black-listed director Herbert Biberman, who had directed the highly acclaimed 1954 film portraying a New Mexican miner's strike Salt of the Earth, created Slaves, released in 1969, about a slave rebellion in Kentucky in the 1850 , but it got poor reviews and a truncated release ${ }^{18}$. The same year Italian director Gilles Pontecorvo's Burn! starred Marlon Brando as a British agent fomenting a slave rebellion in the Caribbean ${ }^{19}$.

Other memorable global cinematic slave narratives of the era include Sergio Giral's The Other Francisco (Cuba, 1975), which brilliantly counterposes ideological takes on slavery in Cuba with its brutal everyday realities, and Tomas Gutierrez Alea's The Last Supper (Cuba, 1976), which deploys innovative modernist techniques to portray a slave rebellion in Cuba and its violent suppression $^{20}$. No major film, however, portrayed the oppressive conditions of

\footnotetext{
18. As I write on January 1, 2014, Slaves is available on Amazon Instant Video, but I could not find a DVD release, nor was there much critical discussion about the film -- which I saw in Paris in the 1970 and recall it had a cult status in some circles.

19. On Burn!, see Carlo Celli, (2005). Marlon Brando claims: "I did some of my best acting in Burn!" (Brando, 1994, p. 364). I have not yet been able to consult Michael T. Martin and David C. Wall, (2013, pp. 445-467).

20. Tomas Gutierrez Alea's The Last Supper is analyzed in Davis (2000), and John D.H. Downing, "Four Films of Tomas Gutierrez Alea," in Film and Politics in the Third World, edited by John D.H. Downing (1987, pp. 279-302). Downing's excellent anthology also contains an interview with The Other Francisco director Sergio Giral who discusses his films and asserts that the period of intense slavery in Cuba prior to 1868 remains a blind-spot in Cuban history; see Sergio Giral, "Cuban Cinema and the Afro-Cuban Heritage," (pp. 267-278).
} 
slavery on a U.S. plantation, and from the actual narrative of a slave who was kidnapped and spent twelve years on a southern plantation before gaining release until, first, Gordon Parks and then Steve McQueen provided cinematic versions of Solomon Northup's narrative 12 Years a Slave which brutally revealed the horrific conditions of slavery in the United States in the 1840 s. Given the current significance of McQueen's film, I'll start with an introduction to McQueen's work, will then turn to Gordon Park's 1984 PBS movie, and then will compare the two versions of Northup's narrative.

Steve McQueen was born on October 9, 1969 in London, England of BritishGrenadian descent as Steve Rodney McQueen. First emerging in the public eye as an artist, McQueen attended Chelsea School of Art, London in 1989-1990, followed by study in Goldsmith's College, London, in 1990-1993, and the Tisch School of the Arts, New York University, New York, during 1993-1994. Known for video installations and short films, McQueen won the coveted Turner Prize in 1999 for his film-installation work and exhibition at the Institute of Contemporary Arts (ICA) in London, which I happened to attend, recalling powerful images of bodies, both in his installations and short films ${ }^{21}$.

McQueen was awarded the O.B.E. (Officer of the Order of the British Empire) in the 2002 Queen's Birthday Honours List for his services to the Arts, and served as the Official War Artist for Iraq in association with the Imperial War Museum in 2003. In 2006, McQueen created a sheet of stamps of portraits commemorating the deaths of British soldiers in Iraq, and was appointed Commander of the Order of the British Empire in 2011 for his contribution to the visual arts. In 2013, at the time of the release of 12 Years a Slave, McQueen was nominated as one of the six finalists for the prestigious Hugo Boss award, given for exceptional achievement in the arts (Vogel, 2013).

Steve McQueen achieved global acclaim as a movie director by helming a highly acclaimed film Hunger (2008) that depicted a 1981 hunger strike by IRA militants, focusing on the slow death through hunger attrition of Bobby Sands, played by Michael Fassbinder who would play key roles in McQueen's next two projects. Hunger was distinguished by long takes focusing on Sands' body, registering beatings, isolation, sores and wounds, and increasing emaciation

21. McQueen's art work and short films are described in the Wikipedia entry at http://en.wikipedia.org/wiki/Steve_McQueen_(director) (accessed December 16, 2013). 
during the hunger strike, until Sands' life literarily departed his body by the end of the film. The beatings and emaciation scenes were intercut with sequences depicting the everyday life of a guard, with one resonant image showing a guard turning aside and crying during a brutal beating, and with scenes with Sands' parents, where at first he tried to convince them that all was "grand."

Hunger marked McQueen as a major cinematic talent, and his following film Shame (2011), depicting Michael Fassbinder as a man possessed by sexual obsession, also got excellent reviews and marked McQueen as a rising figure in world cinema. Shame focuses intensely on a New York corporate executive Brandon (played by Fassbinder), and the film centers on the character's face and body, often isolating him in long shots of a barren urban environment, apparently denoting his alienation, interspersed by fragmentary and quickly edited images of his repeated sexual coupling, and relieved by expository sequences showing him interacting with fellow workers, women, and his troubled sister (Carey Mulligan), who comes to live with him. The focus on individual characters in long takes, and alternating close-ups of their faces with interactions with their environment, unfold in a modernist aesthetic space that finds beauty and resonant images in multiple locations and situations, punctuated by a highly fragmentary narrative, characterizes McQueen's first two films. 12 Years a Slave (2013), replicates that this style, yet deploys a more classical narrative structure than his previous films by following the contours, if not always the letter, of Solomon Northup's tale.

McQueen's cinematic rendition of Solomon Northup's 12 Years a Slave (2013) has indeed catapulted McQueen to the highest reaches of global cinema with the film winning major awards and critical acclaim for the director and cast ${ }^{22}$. Reflecting on the film's origins and gestation, McQueen has noted:

Three and a half years before finishing the production of Twelve Years a Slave I was lost.

I knew I wanted to tell a story about slavery, but where to start?

\footnotetext{
22. After its showing at the Toronto Film Festival, critics were claiming that 12 Years had a lock on the Oscars and other major awards. See Catherine Shoard (2013) premieres to ecstatic reactions and Oscar lockdown. Steve McQueen's account of a free man sold into slavery wins awards buzz, a standing ovation, and praise for its director from producer/star Brad Pitt." The Observer, September 6, 201323.04 at http://www.theguardian.com/film/2013/sep/o7/12-years-a-slave-toronto-premiere (accessed September 16, 2013). For a compilation of early praise for 12 Years, see Anna Silman (2013).
} 
Finally, I had the idea of a free man kidnapped into bondage, but that's all I had. I was attracted to a story that had a main character any viewer could identify with, a free man who is captured and held against his will. For months I was trying to build a story around this beginning but not having great success until my partner Bianca Stigter, a historian, suggested that I take a look at true accounts of slavery. Within days of beginning our research, Bianca had unearthed Twelve Years a Slave, by Solomon Northup.

"I think I've got it," she said. If ever there was an understatement. The book blew both our minds: the epic range, the details, the adventure, the horror, and the humanity. It read like a film script, ready to be shot. I could not believe that I had never heard of this book. It felt as important as Anne Frank's diary, only published nearly a hundred years before.

I was not alone in being unfamiliar with the book. Of all the people I spoke to not one person knew about Twelve Years a Slave. This was astonishing! An important tale told with so much heart and beauty needed to be more widely recognised. I hope my film can play a part in drawing attention to this important book of courage. Solomon's bravery and life deserve nothing less. ${ }^{23}$

In an American Cinematique showing of 12 Years a Slave with Steve McQueen present to do the Q\&A that I attended at the Aero Cinema in Santa Monica on December 13, 2013, John Singleton introduced McQueen, claiming that this was the first time that anyone had really shown what slavery was all about. Singleton cited the white-washing of slavery in Hollywood films like Birth of the Nation, which Singleton claimed began the trajectory of modern American cinema, while also referring contemptuously to Uncle Tom's Cabin as examples of Hollywood's inability to depict slavery in a realist and critic fashion. During the Q\&A, McQueen too claimed that Hollywood cinema had produced an idealized view of slavery in films like Gone With the Wind, Showboat, and other whitewashed versions of slavery, while he asserted that he wanted to present a real and true depiction of its' horrors. McQueen marveled that he had never heard of Solomon Northup who had been disappeared from history. He also proclaimed the burning need to go back and cinematically explore the 400 year-old history of slavery in the Americas, and noted that while the four years of World War II

\footnotetext{
23. Extracted from the new edition of Twelve Years a Slave by Solomon Northup, published by Penguin Classics (London, 2013), and cited from Steve McQueen, "Twelve Years a Slave: the astonishing book that inspired my film. In trying to create a film about slavery I barely knew where to start - until my partner, historian Bianca Stigter, uncovered a true account of slavery that blew our minds." The Guardian, December 2, 2013 at http://www.theguardian.com/culture/shortcuts/2013/dec/o2/twelve-years-a-slavebook-inspired-film-solomon-northup (accessed December 20, 2013).
} 
had generated hundreds, perhaps thousands, of films, the long history and experience of slavery had generated few films ${ }^{24}$.

\section{The first major post-1960s African American director}

Neither McQueen nor Singleton mentioned Gordon Parks' relatively unknown PBS “American Experience" movie of 1984 Solomon Northup's Odyssey, based on Northup's book 12 Years a Slave, 25 nor did they mention Spielberg's Amistad or other efforts to represent slavery such as Herbert Biberman's Slaves (1969), Gilles Pontecorvo's Burn! (1969), Sergio Giral's The Other Francisco (1975), and Tomas Gutierrez Alea's The Last Supper (1976), all powerful depictions of slavery, which also portray forms of resistance. Yet McQueen has undeniably produced one of the most compelling indictments of slavery in contemporary cinema, and to highlight his achievement, I will contrast it to Gordon Parks' more modest 1984 Solomon Northup's Odyssey, comparing Parks' classical realist aesthetic with McQueen's more modernist modes of representation.
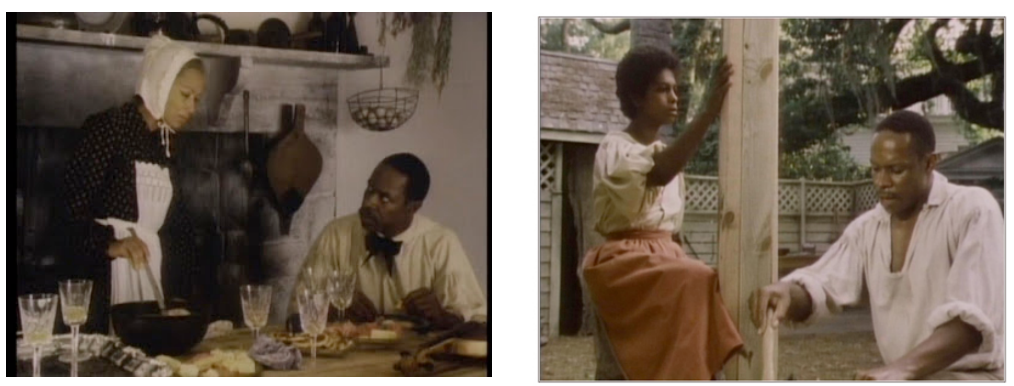

Solomon Northup's Odyssey (Gordon Parks 1984). Avery Brooks as Solomon Northup in the TV series American Playhouse, aired on December 1984 .

The legendary Gordon Parks began as a photographer and visual artist, turning to literature and then film to produce a well-received cinematic version of his novel of growing up black in Depression-era Kansas The Learning Tree (1969) (Parks, 2005 and 1987). Born Gordon Roger Alexander Buchanan Parks on November 30, 1912 in Fort Scott Kansas, Parks died after an illustrious life on March 7, 2006 at the age of 93 in New York City. After a hard scrabble youth during the Depression, Parks got a camera at the age of 25, won a photography fellowship with the Farm Security administration (FSA) for an exhibition of

\footnotetext{
24. McQueen tells a similar story in an interview with Dan P. Lee, "Where It Hurts: Steve McQueen on Why 12 Years a Slave Isn't Just About Slavery," Vulture, December 8, 2013 at http://www.vulture.com/2013/12/steve-mcqueen-talks-12-years-a-slave.html (accessed December 20, 2013).

25. The only comparison of McQueen's 12 Years a Slave to Park's Solomon Northup's Odyssey that I have so far found is Bilge Ebiri (2013).
} 
photos of a Chicago South Side black ghetto and trained with Roy Stryker on FSA projects. After the war, Parks became a freelance photographer for Vogue, and eventually became world famous for his work as a photographer and writer for Life magazine, producing stories and award-winning pictures of African American political leaders, everyday life, and the Civil Rights movement, in which he participated and became close to many of its leaders, including Malcolm X, who named Parks godfather of one of his children.

In one of his several autobiographies, A Hungry Heart, Parks recounts his early life and how he wrote and published The Learning Tree and then became the first major post-1960s African American director, as he directed the film of his autobiography and then went on to make Shaft (1971) and Shaft's Big Score (1972). The latter became landmarks in the emerging blaxploitation genre, which featured strong African American males confronting a corrupt white power structure (Kellner-Ryan, 1988; Koven, 2010). These genre films were followed by a biopic about the famous blues singer Leadbelly (1975), which Parks considered his best film. ${ }^{26}$ Produced on a modest budget for public television, Parks then went on to direct Solomon Northup's Odyssey (1984), which deploys cinematic realism to provide a low-key but moving version of Northup's 12 Years a Slave. In his memoir, A Hungry Heart, Parks recalls:

I spent the next two weeks selecting my crew. It was a ticklish task. I had chosen to shoot the film in the Deep South, especially in the areas where Solomon had spent his gruesome time. I wanted a mixed crew, perhaps to show Southerners how Whites and Blacks could work peacefully together. Hiro Narita, a Japanese-American with great talent, was picked to be my cinematographer. The producer and the assistant director were Black. A good part of the technical crew was White ... When we arrived in Savannah, Georgia, the Whites there goggled at the strange mix of people. For a few days they watched with furious eyes. Eventually they saw what was happening. Ink, amber, and honey were flowing together peacefully. It had never occurred to some of the Whites that these different races could enjoy eating beside one another" (Parks, 2005, p. 333).

Both Parks and McQueen follow fairly closely Northup's narrative of how he was kidnapped in Washington, D.C. in 1841 and sold into slavery, working on

\footnotetext{
${ }^{26}$. Parks writess: "Although the box office did not agree, I will always feel that Leadbelly was my strongest and most ambitious film. It was the story of a real-life musician called the King of the Twelve String Guitar. Huddie Ledbetter's sorrowful plight gave an honest look at the bigotry that was so overwhelming in the 1920 and 1930s." (Parks, 2005, p. 323). I recall Parks making similar claims for Leadbelly during an exhibition of his work at the Laguna Gloria Art Museum in Austin, Texas in the 1970s.
} 
plantations in Louisiana for 12 years before his release ${ }^{27}$, although they present distinct cinematic renditions of the text. McQueen repeatedly stated at the Aero that he wished to find cinematic means of telling the story through an eyebrow, a tear, objects, a sequence of images, and juxtaposition between the beauties of nature and horrors of slavery. Shot by his recurrent cameraman Sean Bobbitt, McQueen's version of 12 Years a Slave was written by John Ridley, and premiered at the Telluride Film Festival on August 30, 2013. The film was given a limited release in the United States on October 18, 2013, with a nationwide release on November 1, 2013. McQueen told the Aero crowd that he shot the film in 35 days with one camera, but had long thought of the story and worked with Ripley on the script, bringing in Hans Zimmer to do the music once the shooting and editing was finished with the first cut.

Signaling his modernist aesthetic, McQueen's 12 Years opens with a montage of resonant images of slave life, including work cutting sugar cane in a plantation field, followed by the transmutation of a bowl of ripe berries into ink with which Northup will write his narrative, images that will be reprised in the unfolding of the film. McQueen's cinema has been marked by the search for resonant images that capture the heart of a situation, alternating long takes with relatively quick cuts in a modernist aesthetic that breaks the rules of narrative continuity and conventional cinematography.

After an opening montage, McQueen cuts to an idyll of Solomon Northup (played by Chiwetel Ejiofor), ${ }^{28}$ as a free black man living in New York, who, accompanied by his well-dressed wife and children, enter a shop where he is respectfully recognized by the shop owner, while a slave named Jasper appears dumbstruck at the sight of a free African-American family, signifying Northup's

\footnotetext{
27. There is a scholarly edition of Solomon Northup, Twelve Years a Slave, co-edited by Sue Eakin and Joseph Logsdon, Library of Southern Civilization: Louisiana State University Press, 1968. The book was expanded and re-issued in August 2013 as Solomon Northup: The Complete Story of the Author of Twelve Years a Slave, edited by Clifford W. Brown, and Rachel Seligman (New York Praeger, 2013). I bought a reproduction of the original publication from Amazon brought out to coincide with the release of McQueen's film with the original publication material in the frontpiece, from which I'll cite pages; the subtitle of the original carries the eyebrow-raising Narrative of Solomon Northup, citizen of New-York, kidnapped in Washington city in 1841, and rescued in 1853, from a cotton plantation near the Red River, in Louisiana; I also draw from an online version of the original printed text at https://archive.org/stream/twelveyearsslaveoonortuoft/twelveyearsslaveoonortuoft_djvu.txt (accessed December 15, 2013).

28. Chiwetel Ejiofor had the role of translator in Amistad (see Note 8) and was achieving global renown in roles as an African immigrant selling illegal body parts in Stephen Frears's Dirty Pretty Things (2002) and playing against type a flamboyant drag queen who saves a failing shoe factory from bankruptcy in Kinky Boots (2005). It is his riveting role in 12 Years a Slave, however, that is propelling him to multiple award nominations and superstardom.
} 
comfort in his situation and status as a free man. The film cuts quickly to a scene of Northup bidding his wife and children farewell, as she leaves to take a temporary position as a cook. Soon after, Solomon meets two men who praise his talent as a fiddler and offer him money to join them with a temporary job in the circus, for which they tell him that he will be well-paid. Soon after, Northup finds himself in chains in a prison in Washington and rages in despair.

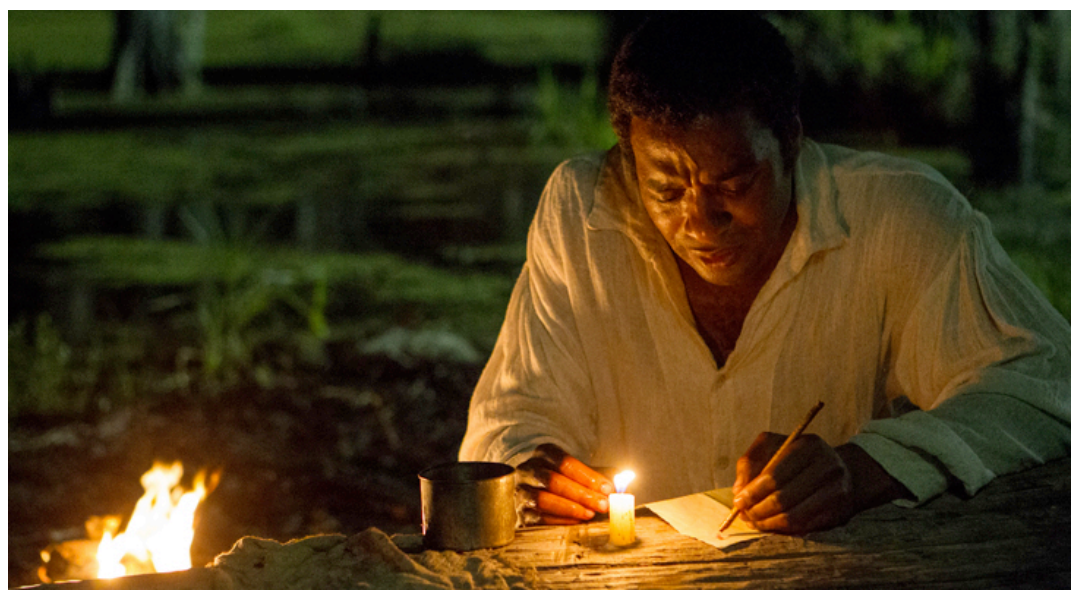

12 Years a Slave (Steve McQueen 2013). Chiwetel Ejiofor as Solomon Northup

Hence, while Solomon Northup opens his 1853 narrative with a detailed genealogy of the history of his family and how he became a free black man and then married, had a family, and moved from a farm where the family had worked for some years to the town where he hoped to advance himself as a carpenter and fiddler, McQueen chooses fragmentary resonant images organized in a modernist collage to depict Northup's fall from freedom into the bondage of slavery.

\section{Avant-garde modernism and conventional narrative}

Gordon Parks, by contrast, in Solomon Northup's Odyssey, cuts from a moon shining in a dark night to an interior with couples happily dancing to Northup's exuberant fiddling. Departing from the narrative of the book, Parks cuts to a home scene where Northup argues with his wife about money, first forbidding her to go accept a job as a cook that would force her temporarily to leave the house, and then attempting to justify their move from farm to city and his inability to gain steady work as a carpenter, a conflict not presented in Northup's book, which has but a few idealized remembrances of his wife and family. Parks, by contrast, uses many flashbacks to Northup's happy life with his 
family and to his wife making efforts to find him and procure his freedom. The need for family income motivates Northup in Parks' story into accepting the two strangers' offer to leave his New York home and travel to Washington D.C. on a promise of employment as a violinist with a show. Hence, Parks deploys a more conventional narrative form to tell Northup's story, providing motivation for his actions, a sense of his relation to his wife and previous life, and more conventional narrative pacing and continuity than the avant-garde modernist McQueen.

Both Parks and McQueen depict Northup waking up in a prison in Washington, D.C., with Northup protesting his bondage and then being beaten into submission, a beating especially dramatized in McQueen's powerful rendition. In a long take with darkness and shadows, McQueen renders the sound of Northup being beaten with a wooden panel after waking up in chains. Cinematographer Sean Bobbit noted in an interview: "We're seeing Solomon's reaction, but he's hidden in the shadow. That allows us to project our feelings onto him. The audience has to search the frame a bit. Once you get them engaged like that, I think that heightens their emotional involvement." (Ebiri, 2013a). Indeed, throughout the film, McQueen deploys modernist strategies of excess to demonstrate the horrors and inhumanity of black slaves being beaten into submission, with repeated images of whips loudly lashing black bodies, close-ups of bloodied scars, and lacerated and humiliated humans, and the sounds of whips tearing the flesh, and of the humans subjected to such brutal violence. Finally, McQueen constructs an unsettling sound montage with Hans Zimmer's music interlaced by unnatural natural sounds of insects, birds, and ambient nature pierced by bodies being brutalized and individuals screaming in pain.

Parks, however, frames Northup's sudden enslavement more ironically, cutting from a close-up of the ivory white building of Congress, just minutes from the slave-pit where Northup finds himself imprisoned. This follows Northup's text where he describes how "we passed, handcuffed and in silence, through the streets of Washington through the Capital of a nation, whose theory of government, we are told, rests on the foundation of man's inalienable right to 
life, LIBERTY, and the pursuit of happiness! Hail! Columbia, happy land, indeed!" (2013, p. 13).

The vicious trader Theophilus Freeman played by Paul Giamatti in McQueen's film beats Northup repeatedly when he refuses to utter his slave name and accept his status, declaring: "My sentimentality extends the length of a coin" capturing the nexus of greed and pathological viciousness at the bottom of the slave trade. Indeed, the ironically named Theophilus Freeman, played as utterly repellent by Giamatti, encourages potential customers to check the auctioned slaves' teeth, body, and reactions to detect the value of the merchandise.

In both films, Solomon Northup learns of the extremity of his changed condition as he is taken from a slave pen to go to the auction, learning that his new name is "Platt." Solomon is forced to accept the name for much of the rest of the story, dramatizing how slavery stole name and identity from their rightful owners. Another trope of the utter inhumanity of slavery occurs at the auction block in both films when the children of a slave woman Eliza are torn from her and sold to other owners, a story found in Northup's narrative which McQueen intensely dramatizes, showing Eliza writhing and screaming in utter despair.

Parks will later depict in some detail the slow workings of justice through which Northup is eventually released, while McQueen takes him from one horror to another until in the depths of degradation and despair suddenly lawmen show up to tell Northup that he is free. Relatively early in the movie when Northup discovers himself in captivity, Parks presents a long narrative scene with Northup insisting to the slave pen overseer that he was a free man, while the white man declared that he was a slave and the property of his new owner, whipping him repeatedly when he claims he was a free man and not a slave who was the property of someone else. The contrast between Northup as a free man and a slave who is the property of others informs Parks' narrative as a leitmotif, frequently returned to and articulated.

McQueen, by contrast, tends to use images and not dialogue to delineate his themes, deploying resonant images and montage to depict Northup's sudden descent into a slave pen and shipment south to New Orleans, where he is sold at a slave market and taken into bondage and the horrors of plantation life in Louisiana. McQueen filmed much of the location in a region where slaves once 
lived and worked the land and exploits the landscape, decaying Southern mansions, and sounds of the region to use the aesthetics of the site as a backdrop to the unspeakable brutality and monstrosity which his film will attempt to capture.

Both Parks and McQueen follow Northup's narrative of contrasting relatively humane with exceptionally monstrous slave owners. Following Northup's text, Solomon, now Platt, finds himself on the plantation of a well-meaning but ineffectual owner William Ford, whom Northup says later becomes a Baptist minister. ${ }^{29}$ Played by Mason Adams in Parks' rendition, Ford quickly recognizes Platt/Northup's abilities, especially, when he supervises building a raft to ship lumber down a river, a scene replicated by McQueen's Ford (Benedict Cumberbatch).

Northup mentions the cruelty of a carpenter John M. Tibeats employed by Ford (2013, p. 39), and one of the most disturbing scenes in both films involves an episode where Platt/Solomon becomes involved in an altercation with the sadistic overseer Tibeat. ${ }^{30}$ McQueen uses actor Paul Dano to play Tibeats overthe-top, excessively tormenting Platt, and in one scene McQueen has Dano singing a racist song of the era, "Run Nigger Run," as he lords himself over the slaves. McQueen presents Tibeats as a crazed white tormentor of blacks, revealing McQueen's propensity for modernist shock and exaggeration techniques that go beyond Solomon Northup's text, or Parks' more traditional realist mode of representation.

In one telling episode, after being accused by Tibeats of using the wrong nails on a house construction (whereas Platt/Northup insisted he used exactly the nails he was told to), Northup finally explodes with anger after Tibeats began to lash him and takes up the lash and fiercely beats his tormentor, a scene that McQueen draws out at length. After his outburst, Platt/Northup is seized and

\footnotetext{
29. Northup says of Ford "there never was a more kind, noble, candid, Christian man than William Ford," although "the influences and associations that had always surrounded him, blinded him to the inherent wrong at the bottom of the system of Slavery. He never doubted the moral right of one man holding another in subjection. Looking through the same medium with his fathers before him, he saw things in the same light. Brought up under other circumstances and other influences, his notions would undoubtedly have been different" (2013, p. 33). Here Northup reveals impressive insight into how social conditions produce values, behavior, and ideologies, points articulated during the same period by Marx and Engels in The German Ideology and Communist Manifesto.

30. (Northup, 2013, pp 40ff) for his narrative account of the episode. Northup's text is more complex and detailed than McQueen's modernist film rendition with its long expository passages where Platt is rented out to Tibeats, who torments him, but whose labor is managed by an overseer Mr. Chapin who does not appear in McQueen's condensed version.
} 
hung up on a tree and left dangling close to death overnight, a scene which McQueen aestheticizes with resonant images of Platt/Northup dangling from the tree, his feet barely able to touch the ground in order to keep him from hanging to death. The iconography of lynching and images of blacks hanging from trees is, of course, a powerful and disturbing one that McQueen exploits to deeply instill the horrors and inhumanity of slavery on the audience.

\section{Edwin Epp's violence. Multifaceted human being, vicious demon}

For both Parks and McQueen, Ford is shown as ineffectual and forced to sell his slaves to Edwin Epps, a much harsher owner who represents the cruel inhumanity and brutality of slavery for Northup. Parks' Epps (John Saxon) is shown as harsh and uneducated and held in contempt by his higher class wife, and while brutal, he is not the absolute monster played by Michael Fassbinder. At the Aero Q+A, McQueen insisted that he wanted to portray Epps as a human, but in my repeated viewings of Solomon Northup's Odyssey and Twelve Years, Parks' depiction of Epps presented a more multifaceted human being, precisely in his limitations and foibles, while McQueen/Fassbinder's Epps is demonic in his viciousness. McQueen has a character narratively describe Epps to Platt/Northup as a "nigger breaker", and his Epps reaks with sadism, psychotic violence, and demonic evil beyond the human. ${ }^{31}$ The excess in Fassbinder's Epps, in contrast to the restraint in which the malevolent Epps is portrayed in Parks' film, comes out clearly during a night scene in which Epps is shown genuinely enjoying dancing with the black slaves as Solomon plays the fiddle, while Epps in the McQueen version dances maniacally, like a man possessed. McQueen shows Epps sexually obsessed by a comely slave Patsey (Lupita Nyong'o), who is portrayed by McQueen as the best worker, repeatedly outpicking the male slaves in the cotton field. ${ }^{2}$ The theme of sexual obsession

31. Actually, Northup himself notes Epps' "inhuman throng” from which he has escaped and describes Epps in the same passage as:

a man in whose heart the quality of kindness or of justice is not found. A rough, rude energy, united with an uncultivated mind and an avaricious spirit, are his prominent characteristics. He is known as a "nigger breaker," distinguished for his faculty of subduing the spirit of the slave, and priding himself upon his reputation in this respect, as a jockey boasts of his skill in managing a refractory horse. He looked upon a colored man, not as a human being, responsible to his Creator for the small talent entrusted to him, but as a "chattel personal," as mere live property, no better, except in value, than his mule or dog. (Northup, 2013, p. 75).

32. Northup also describes the almost superhuman features of Patsey in a relatively long passage in his narrative (pp. 77-78), writing: 
was the topic of McQueen's previous film Shame (2012), and it is played out to the extreme with Fassbinder's Epps portrayed as a vicious man in the throes of sexual passion and violence.

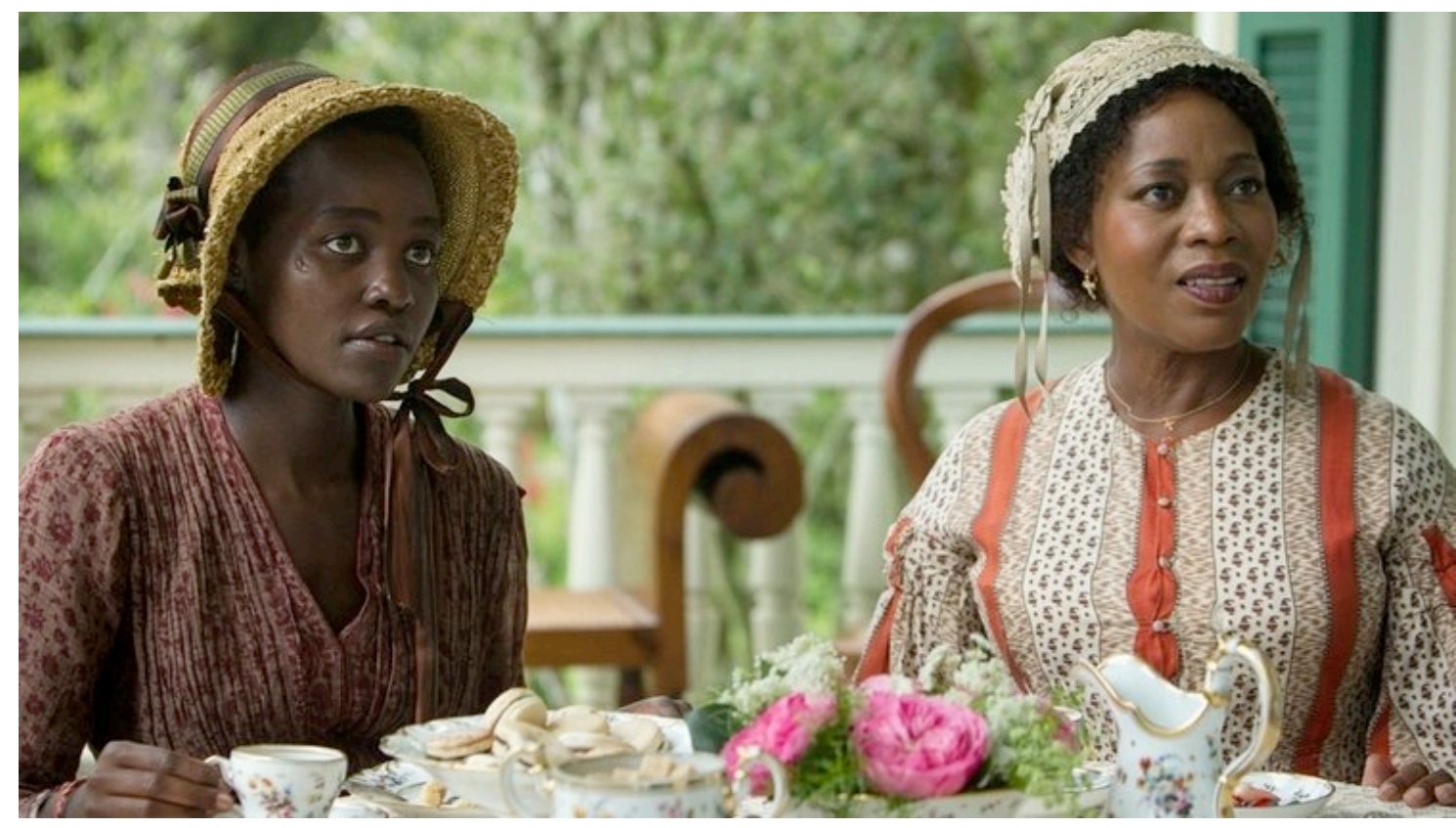

12 Years a Slave (Steve McQueen 2013). Lupita Nyong'o as Patsey and Alfre Woodard as Mistress Harriet

Patsey was slim and straight. She stood erect as the human form is capable of standing. There was an air of loftiness in her movement, that neither labor, nor weariness, nor punishment could destroy. Truly, Patsey was a splendid animal, and were it not that bondage had enshrouded her intellect in utter and everlasting darkness, would have been chief among ten thousand of her people. She could leap the highest fences, and a fleet hound it was indeed, that could outstrip her in a race. No horse could fling her from his back. She was a skillful teamster. She turned as true a furrow as the best, and at splitting rails there were none who could excel her. "When the order to halt was heard at night, she would have her mules at the crib, unharnessed, fed and curried, before uncle Abram had found his hat. Not, however, for all or any of these, was she chiefly famous. Such lightning-like motion was in her fingers as no other fingers ever possessed, and therefore it was, that in cotton picking time, Patsey was queen of the field.

She had a genial and pleasant temper, and was faithful and obedient. Naturally, she was a joyous creature, a laughing, light-hearted girl, rejoicing in the mere sense of existence. Yet Patsey wept oftener, and suffered more, than any of her companions. She had been literally excoriated. Her back bore the scars of a thousand stripes; not because she was backward in her work, nor because she was of an mindful and rebellious spirit, but because it had fallen to her lot to be the slave of a licentious master and a jealous mistress. She shrank before the lustful eye of the one, and was in danger even of her life at the hands of the other, and between the two, she was indeed accursed. In the great house, for days together, there were high and angry words, poutings and estrangement, whereof she was the innocent cause. Nothing delighted the mistress so much as to see her suffer, and more than once, when Epps had refused to sell her, has she tempted me with bribes to put her secretly to death, and bury her body in some lonely place in the margin of the swamp. Gladly would Patsey have appeased this unforgiving spirit, if it had been in her power, but not like Joseph, dared she escape from Master Epps, leaving her garment in his hand. Patsey walked under a cloud. If she uttered a word in opposition to her master's will, the lash was resorted to at once, to bring her to subjection; if she was not watchful when about her cabin, or when walking in the yard, a billet of wood, or a broken bottle perhaps, hurled from her mistress' hand, would smite her unexpectedly in the face. The enslaved victimof lust and hate, Patsey had no comfort of her life (Northup, 2013, p. 77).

Parks' substitution of a more understandable character Jenny for Patsey shows his use of familiar character types in a classically realist narrative. McQueen, by contrast, goes for extremes and shock effects, making his Patsey even more flamboyant and almost superhuman than the extravagant description in Northup cited above. 
Patsey also attracts the hatred of Epps' wife (Sarah Paulson), who McQueen initially plays as sympathetic, but who becomes increasingly monstrous herself as the plot evolves and her jealousy explodes, driving her to demand that Patsey be whipped, in a violent scene that is almost unbearable in its intensity. Interestingly, Parks' representation of Epps' wife is much softer, and for the disruptive character Patsey, Parks substitutes a gentler character Jenny (Rhetta Greene), who is shown turning to Platt/Northup for affection and love when they find themselves newly enslaved on the plantation, but who turns to Epps out of convenience and a desire to elevate herself.

In Parks' rendition, Platt is ordered by Epps to whip Jenny to placate Epps' wife, and Platt takes her into a barn where he pretends to beat her, while in McQueen's version Platt is forced to whip Patsey repeatedly in an almost unbearable scene. The long takes which show Patsey's brutal beating, as well as other long takes that feature whippings, beatings, and rape, point to a pornography of violence evident throughout McQueen's major films.33 As noted, Hunger features long takes of Bobby Sands being brutally beaten, focusing on the effects and aftermath of his torture. The hunger strike scenes of Sands feature interminably long takes of his emaciated body, sores, and sunken hollow eyes. Strangely, the sex scenes and nude bodies of Shame, also fetishistically shot in long takes, are not really pornographic in the sense of evoking arousal, while the images of violence in Hunger and 12 Years are pornographic in their explicitness, overtness, and extreme violence.

Yet the quasi-pornographic violence is interspersed in McQueen's 12 Years, with moments of aestheticism bursting out in extended lyrical shots of plantation beauty and Louisiana landscape, and a rich sound montage of natural sounds of a teeming southern Nature, interspersed with Hans Zimmers' haunting score. In an odd scene not found Northup's narrative, Solomon goes to a neighboring plantation to fetch Patsey who is having tea with an African American pl. antation Mistress Shaw (Alfred Woodard) who has gained freedom of a sort by marrying a wealthy white plantation owner, highlighting the bizarreness of plantation life in an almost surreal tableau.

33. McQueen’s film was dismissed as “torture porn” in an attack by Armond White (2013). 
To the criticism that his 12 Years aestheticizes violence, McQueen has answered in reviews: "Think of Goya. He painted the most horrendous acts of violence of his era, in the most beautiful way. The beauty was a way of saying, 'Look at this, I want your attention" (Ebiri, 2013a). Like Spielberg in Amistad, McQueen uses Goya-esque contrasts of darkness and light, captivity and freedom, and powerful images of suffering and degradation, deploying aesthetics to convey messages about domination and liberation, good and evil.

One might contrast the motifs of religion in Northup, Parks, and McQueen's telling of 12 Years. In his memoir, Northup has conventional remarks toward God and religion, while both Parks and McQueen illustrate how slave-owners use the Bible to legitimate slavery and to attempt to get slaves to submit to their unholy and inhumane living and working conditions. While Ford is presented in all the three texts as a relatively humane slave-owner, his use of scriptures to attempt to help his slaves come to accept their condition is present by McQueen as hypocritical and mendacious, and there are few if any hints of religious redemption in McQueen's bleak cinemascape.

McQueen's 12 Years portrays Platt/Northup driven to the depths of despair, finally thinking that it was impossible for him to escape, while Parks' narrative, by contrast, pictures Northup's wife continually making efforts to rescue him and the narrative movement depicts in detail the steps taken to finally rescue Northup. Parks' film, for instance, shows a letter sent relatively early in the film reaching his wife and encouraging her to keep up the search for her missing husband. Later, in both Parks' and McQueen's narrative, a sympathetic carpenter Sam Bass is taken into Northup's confidence and he tells him who he really is and implores him to send a letter telling his wife where he is currently enslaved. In McQueen's version, Bass (played by a very sympathetic Brad Pitt who also served as one of the film's producers) is the one white person in the film who connects to Northup on a personal level and promises to deliver his letter and take up his case. He responds sympathetically to Northup's plight and tells him: "Your story is amazing, and in no way good." Moreover, Bass is the one character allowed by McQueen to articulate a critique of slavery, telling 
Epps that "If you don't treat them as humans, then you will have to answer for it," an argument Epps is incapable of understanding 34 .

In McQueen's version, Bass leaves the plantation to seek work and adventures elsewhere and Northup falls into deep despair, believing that Bass too has failed to come to his aide. A burning letter denotes the depths of Northup's despair and hopelessness, just before authorities arrive at the plantation to tell Northup he is free and to take him back north, while Epps and his wife look on in amazement and anger at seeing their idyll of ownership undermined.

\section{Conclusion.}

Parks and McQueen both end their versions of 12 Years with Northup being happily reunited with his wife and children, and both end with graphic titles noting that Northup attempted to bring criminal charges against the kidnappers. The graphics in both films indicate that Northup, as a black man, could not testify in court, pointing to the continued ills of slavery and segregation after Northup's liberation, a condition that would lead to the Civil War and decades of unending civil rights struggles.

Yet for a film that deals with such a politically explosive topic like slavery, McQueen's 12 Years is curiously conventional in its explicit liberal ideology which focuses on the individual male hero and his fate. Although McQueen breaks with many conventional Hollywood narrative and aesthetic codes, like Spielberg, he follows the individualism of the classical Hollywood cinema with intense focus on the narrative of Solomon Northup and reverential close-ups of actor Chiwetel Ejiofor with a centering of the central character in almost every scene. This epic of individual survival also features the typical Hollywood happy ending, signaled in advance by those who know that the title "12 Years a Slave" signifies a period of captivity which Northup survives and is liberated from.

In McQueen's film, Northup embodies a largely conservative individualism concerned above all with his liberty and family. When aboard a slave ship en

34. Northup presents Bass as "a man whose true heart overflowed with noble and generous emotions... He was liberal to a fault," (2103, p. 111). Gordon Parks introduces Bass as a contrarian arguing against slavery with Epps and a group of Southern gentleman on a plantation porch. Parks' Bass good naturedly prods Platt/Northup on his views of slavery, and then befriends him as they work together, promising to get word to Northup's friends and family up North and getting documents that attest Northup was a free man which he does, making Bass a hero in the narrative of Northup's liberation in the original text and both films. 
route to the slave market in New Orleans, a fellow black tells Solomon that if he wants to survive: "Tell no one who you are. Tell no one you can read and write." Responding, Northup insists: "I don't want to survive. I want to live." Yet once he discovers the nature of his condition, Northup is basically a survivor who throughout the film often acts in an aristocratic manner with cultured dictation and superior skills in many arenas, positioning himself as a highly superior individual human being. At the end of the narrative, once he is told that he is now free, in McQueen's version, Northup absorbs the wondrous looks of the other slaves, who will continue in their miserable condition, wordlessly hugs Patsey, and leaves alone to freedom and a happy reunion with his family.

In Parks' film version, Northup turns and tells an old slave that "I won't forget you," and indeed Northup does write his stunning narrative account of his captivity that described in detail the inhuman system of oppression that inspired abolitionists and would be challenged in the Civil War. McQueen, however, renders the dynamics of his liberation ambiguous, unlike Parks' Solomon Northup's Odyssey which signals the eventual freeing of Northup and the process through which his wife and white patron's search for him are successful. Hence, despite the rigorous modernist aesthetics and brutal depiction of the horrors of slavery, McQueen's 12 Years provides a rather conventional story of survival and endurance, a genre very popular in contemporary Hollywood cinema, embodied in other 2013 films like Gravity, All Is Lost, and Captain Philips.

The most radical political films depicting slavery like Gilles Pontecorvo's Burn! (1969), or Tomas Gutierrez Alea's The Last Supper (1976), feature slave rebellion and portray collective revolt, although they may have a leader like Cinque in Amistad, or José Dolores in Burn!. 12 Years, by contrast, is a narrative of survival and endurance where with one narrative exception, Solomon Northup/Platt accommodates himself to the system in order to survive. Yet in a deeper existential/political register, McQueen's film, like the works of Kafka and Beckett in Adorno's analyses,35 expresses the horror and

35. In "Commitment," T.W. Adorno writes: "It is not the office of art to spotlight alternatives, but to resist by its form alone the course of the world, which permanently puts a pistol to men's heads... Kafka's prose and Beckett's plays, or the truly monstrous novel The Unnameable, have an effect by comparison with which officially committed works look like pantomimes. Kafka and Beckett arouse the fear which 
monstrosity of slavery in ways that capture its pathology and obscenity and provide no redemptive moments except for Northup's survival. McQueen's modernist aesthetic produces images that burn into the deepest layers of the spectators' mind and provide an experience of a horrific history and crisis of humanity that has profoundly shaped American culture and society to this day.

\section{Bibliography}

Adorno, T.W. (1977). Aesthetics and Politics. London: New Left Books.

Bordwell, D. and Janet Staiger and Kristin Thompson (1985). The Classical Hollywood Cinema: Film Style \& Mode of Production to 1960. New York: Columbia University Press; Reprint edition.

Brando, M. (1994). Brando: Songs My Mother Taught Me. New York: Random House.

Bronner S. and Douglas Kellner (eds.)(1983/1988). Passion and Rebellion: The Expressionist Heritage. New York: Universe Books and Bergin Publishers; and London: Croom Helm, 1983; second edition, Columbia University Press, 1988.

Bronner, S. (2012). Modernism at the Barricades: Aesthetics, Politics, Utopia. New York: Columbia University Press.

Brown Clifford and Rachel Seligman (eds.) (2013). Solomon Northup: The Complete Story of the Author of Twelve Years a Slave. New York: Praeger.

Celli, C. (2005). Gillo Pontecorvo: From Resistance to Terrorism. Lanham MD: Scarecrow Press.

Davis, N. (2000). Slaves on Screen. Film and Historical Vision. Cambridge, Mass: Harvard University Press.

Downing, J. (1987). Four Films of Tomas Gutierrez Alea. In John D.H. Downing (ed.), Film and Politics in the Third World (279-302). Brooklyn, New York: Autonomedia.

Eakin, S. and Joseph Logsdon (eds.) (1968). Twelve Years a Slave. Baton Rouge LA: Library of Southern Civilization, Louisiana State University Press.

Ebert, R. (1997). AMISTAD. December 12. http://www.rogerebert.com/reviews/amistad- (accessed November 5, 2013).

Ebiri, B. (2013a). Horrendous Acts in a Beautiful Way: Behind the Scenes of 12 Years a Slave. Vulture, November 13, 2013 at http://www.vulture.com/2013/11/behind-the-scenes-of-12-years-aslave.html (accessed on December 15, 2013)

existentialism merely talks about.... The inescapability of their work compels the change of attitude which committed works merely demand.” (1977, pp. 180, 191). 
Ebiri, B. (2103). A Tale Twice Told: Comparing 12 Years a Slave to 1984's TV Movie Solomon Northup's Odyssey. Vulture, November 11, 2013 at http://www.vulture.com/2013/11/12-years-a-slave-vs-gordon-parks1984-solomon-northups-odyssey.html (accessed December 15, 2013).

Foner, E. (1998). The Amistad Case in Fact and Film. History Matters March 1998) http://historymatters.gmu.edu/d/74/ (accessed November 5, 2013).

Friedman, L. (2006). Citizen Spielberg. Urbana and Chicago: University of Illinois Press.

Kellner K. and Ryan M. (1988). Camera Politica: The Politics and Ideology of Contemporary Hollywood Film. Bloomington, Ind.: Indiana University Press.

Kellner, D. Lincoln in contemporary U.S. culture and politics. Jump Cut 55 (Fall 2013) http://www.ejumpcut.org/trialsite/KellnerLincoln/ (accessed November 5, 2013)

Koven, Mikel J. (2010). Blaxploitation Films. London, UK: Oldcastle Books.

Martin M. and David C. Wall (2013). The Politics of Cine-Memory: Signifying Slavery in the History Film. In Robert A. Rosenstone and Constantin Parvulesu (eds.), A Companion to the Historical Film (445-467). New York and London: Wiley-Blackwell.

Myers, W. (1998). Amistad: A Long Road to Freedom. New York: Dutton's Children Books.

Northup, S. (1968). Twelve Years a Slave (co-edited by Sue Eakin and Joseph Logsdon). Library of Southern Civilization: Louisiana State University Press.

Northup, S. (2013). Solomon Northup: The Complete Story of the Author of Twelve Years a Slave (edited by Clifford W. Brown, and Rachel Seligman). New York: Praeger.

Parks, G. (1987). The Learning Tree. New York: Fawcett.

Parks, G. (2005). A Hungry Heart \{A Memoir\}. New York: Atria Books.

Rediker, M. (2012). The Amistad Rebellion. An Atlantic Odyssey of Slavery and Freedom. New York: Viking.

Sánchez-Escalonilla, Antonio (2005). Steven Spielberg: Entre Ulises y Peter Pan. Madrid: CIE Dossat.

Sánchez-Escalonilla, Antonio (2009). El primer regreso al hogar en el cine de Steven Spielberg. Film Historia 1, (19).

Shoard, C. (2013). Toronto: 12 Years a Slave premieres to ecstatic reactions and Oscar lockdown. The Observer, September 6, 2013. http://www.theguardian.com/film/2013/sep/o7/12-years-a-slavetoronto-premiere (accessed September 16, 2013).

Silman, A. (2013). "Review Roundup: The Most Effusive Praise of 12 Years a Slave," Vulture, October 18. http://www.vulture.com/2013/10/mosteffusive-praise-of-12-years-a-slave.html (accessed December 17, 2013). 
Vogel, C. (2013). Steve McQueen Among 6 Hugo Boss Prize Finalists. New York Times, December

12.

http://www.nytimes.com/2013/12/13/arts/design/steve-mcqueenamong-6-hugo-boss-prize-finalists.html? $r=0$ (accessed December 20, 2013).

White, A. (2103). Can't Trust It. City Arts, October 16, at http://cityarts.info/2013/10/16/cant-trust-it/ (accessed December 16, 2013). 